\title{
КОРЕКЦІЯ ДИТЯЧИХ СТРАХІВ В ДОШКІЛЬНИХ ДИТЯЧИХ ЗАКЛАДАХ МЕТОДАМИ АРТ-ТЕРАПIÏ
}

Стаття присвячена особливостям корекиії дитячих страхів методами арт-терапії. Здійснено спробу розкрити поняття дитячих страхів $i$ вплив їх на подальше формування особистості. Висвітленні основні особливості корекційної роботи з дитячими страхами. Вказано, на важливу роль батьківського впливу на формування $i$ подолання фобій дитини, та на ефективність застосування методів арт-терапії, як психологічного напрямку в боротьбі 3 страхами дитини.

Ключові слова: страх, дошкільний вік, арт-терапія, розвиток особистості, психокорекиія, ігрова діяльність, зображувальна терапія.

Статья посвящена особенностям коррекиии детских страхов методами арт - терапии. Предпринята попьтка раскрыть понятие детских страхов и влияние их на дальнейшее формирование личности. Освещены основные особенности коррекционной работы с детскими страхами. Указано на важную роль родительского влияния в формировании и преодолении фобий ребенка, и на эффективность применения методов арт - терапии, как психологического направления в борьбе со страхами ребенка.

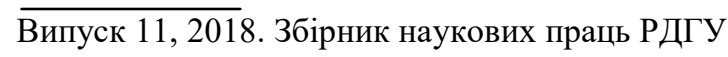


Ключевые слова: страх, дошкольный возраст, арт - терапия, развитие личности, психокоррекиия, игровая деятельность, изотерапия.

Постановка проблеми. У даний час, в умовах соціальної нестабільності, особистість дитини схильна до впливу безлічі несприятливих факторів, здатних не тільки уповільнювати розвиток особистості, але і повернути його в іншому напрямку. Дитина як одна з найбільш тендітних учасників суспільства часом нездатна впоратися 3 негативним ефектом оточуючого світу. Саме це стало причиною проведення ряду експериментальних досліджень, в результаті яких з'ясувалося, що серед можливих наслідків найбільш поширеними є страхи і тривожність. Страх, інакше кажучи, інстинкт самозбереження - це одна з основних емоцій, які загрожують психічному здоров'ю дитини. Першим, хто проаналізував причини виникнення та розвитку емоційно негативних станів, був О. І. Захаров. Він навів безліч статистичних даних, виходячи з різних чинників навколишнього світу: сім'я і її вплив на становлення страхів, статева приналежність, взаємозв'язок вікової динаміки і наявності страхів, адже так як дітям, властиво реальне сприйняття навколишнього світу, їх страхи носять виражений характер і залежать від соціального, психологічного, економічного середовищ і т. д. [1].

Кожен етап дорослішання має свої особливості, в дошкільному віці однією з них є сильна залежність від дорослого, яка згодом впливає на розвиток особистості дитини. Прикладом можуть бути батьки зі підвищеною кількістю страхів, тривожністю або неврозом, що позначається на збільшенні числа страхів у дітей дошкільного віку, в результаті утворюється замкнене коло. Дитяча психіка, на відміну від психіки дорослої особистості, більш сприйнятлива до різноманітних впливів. Вразливість і нездатність протистояти можуть спровокувати виникнення невротичних страхів, які будуть супроводжуватися тривалими переживаннями на тлі перенапруги нервових процесів [2]. У результаті розвитку невротичних страхів дитина стає мало спілкуватися з оточуючими, скутою і напруженою, тому потребує особливої уваги психологів, педагогів і батьків. Позитивний емоційний контакт $€$ фундаментальною основою для нервово-психічного розвитку молодого індивіду, отже, дуже важливо завчасно помітити зміни, що відбуваються 3 дитиною, щоб скорегувати відносини 3 нею.

Для того щоб допомогти дитині впоратися зі страхами, необхідна спеціальна корекційна робота. Сучасна практична психологія пропонує безліч варіантів подолання страхів, при цьому психотерапія в широкому сенсі розглядається як найбільш прийнятний і дієвий засіб. Існують різні види терапії, які використовуються в практичній роботі зі страхами. Одними з найбільш оптимальних для дітей дошкільного віку вважаються, методи арт-терапії, так як в дошкільному віці провідний вид діяльності - гра, а найважливіша продуктивна діяльність - малювання. Таким чином, арттерапевтична практика може забезпечити вивільнення дитини від нав'язаних страхів, i дитина через взаємодію з дорослим освоює елементи самодослідження, саморегуляції і самоконтролю.

Аналіз останніх досліджень і публікацій. Представник біогенетичного напрямку С. Холл поширював біогенетичний закон і на онтогенез страху. Він стверджував, що дитина переживає в процесі свого розвитку страхи, які зазнали тварини, а потім люди на різних етапах антропогенезу. O.I. Захаров, вважав, що розуміння небезпеки, ії усвідомлення формується в процесі життєвого досвіду і міжособистісних відносин, коли деякі індиферентні для дитини подразники поступово набувають характеру погрожуючих впливів. Також проблематикою виникнення і корекції дитячих страхів займалися Ю. Щербатих, В. Овчарова та інші.

Формулювання цілей статті. Наукове повідомлення спрямоване на висвітлення проблеми сутності дитячих страхів та їх корекції.

Виклад основного матеріалу дослідження. Страх є об'єктом вивчення у різних галузях науки - філософії, психології, педагогіки, психіатрії, фізіології і т.д. 3 метою диференціації феномену страху від схожих психологічних станів (тривоги, посттравматичного стресового порушення, фобії) ми визначаємо страх як в цілому негативний емоційний стан, пов'язаний з відображенням в свідомості конкретної загрози для життя і благополуччя, що має на увазі переживання якої-небудь реальної чи уявної небезпеки. Молодший шкільний вік, згідно О. І. Захарову, - це період переходу від інстинктивних до соціально-опосередкованих страхів, які в підлітковому віці трансформуються в соціальні страхи, як загрозу власному благополуччю в контексті відношень з оточенням. Зростає кількість страхів не відповідати соціальним вимогам найближчого оточення сім'ї та школи [1].

Згідно диференціації причин страхів за рівнями соціалізації дитини, детермінанти страхів співвідносяться з рівнем соціалізації. Детермінантами страхів на першому рівні соціалізації - в сім'ї, $\epsilon$ незадоволені потреби в розумінні, прив'язаності, безумовній любові, фізичні покарання, залякування, дефіцит позитивного спілкування з батьками, тривожність батьків, гіперопіка, страшні мультфільми та казки. Детермінантами страхів у дітей на другому рівні соціалізації - в школі, можуть бути: 
подолання критики над похвалою, висміювання недоліків і насмішки ровесників, залякування, відсутність спілкування, розлука 3 об'єктом прихильності. На третьому рівні соціалізації мезосередовище, детермінантами дитячих страхів можуть виступати негативний досвід, стихії, військові дії, перегляд телепередач з сильним емоційним змістом [2].

На думку О.І. Захарова, найбільш успішно, психологічному впливу піддаються страхи в дошкільному та молодшому шкільному віці. Психологічна корекція визначається як «виправлення» $\mathrm{i}$ оптимізація процесу психічного розвитку особистості, яка передбачає використання природних рушійних сил психологічного та особистісного розвитку. При цьому ми враховуємо, що психологічна корекція, здійснювана психологом, що не передбачає виправлення недоліків, які мають органічну основу, і диференціюючи психокоррекцію нормального і аномального розвитку. Основне завдання психокорекційного впливу ми бачимо у формуванні відсутніх або недостатньо розвинених психологічних якостей.У психолого-педагогічній літературі описані різні способи корекції дитячих страхів різного походження. Багато 3 них запозичені з практики лікування неврозів і $є$ різновидом того чи іншого методу психотерапії, зокрема поведінкова і когнітивна психотерапія, психоаналіз, арттерапія, гештальт-терапія та інші [3].

Арт-терапія - це напрямок, що включає в себе безліч областей знань, таких як психологія, медицина, педагогіка, культурологія та інші. В основі арт-терапії лежить художня практика, в ході терапії індивід проектує свої внутрішні переживання за допомогою творчості, використовуючи при цьому безліч мистецьких матеріалів. Цей напрямок терапії дозволяє одночасно працювати з групою дітей як одного, так і різного віку і може бути адаптованим для роботи 3 однією дитиною. Ефективною виявляється для корекції різноманітних страхів, але перш за все тих, які викликані фантазією: боязнь хвороби, напади, стихійних лих, транспорту, казкових персонажів та ін. [5]. Через заняття художньою творчістю арт-терапія зумовлює психологічний вплив і використовується як інструмент для розвитку та гармонізації психічної діяльності людини. Даний напрямок дозволяє проектувати стан свого внутрішнього «Я» на продукт діяльності, позбавляючи дитину від внутрішнього конфлікту і надзвичайної напруги, що, в свою чергу, призводить до звільнення, катарсису. Використанням співтворчості для розвитку особистості в процесі психотерапії, займалися такі психологи, як О. І. Аржанова, І. П. Воропаєва, В. Г. Нечаєва, Р. В. Овчарова, Н. Є. Фаас.

Терапевтичний процес впливає на психіку і дозволяє не тільки знизити кількість страхів, рівень тривожності або агресивність, але і знайти стійкість, впевненість в собі, включаючи позитивні патерни поведінки i переживання. Арт-терапія здатна найбільш м'яко і гуманно підтримати особистість дитини, стрімко примножити ії здатності до самопізнання, що має місце в роботах Дж. Аллана, М. Бурно, О. І.Копитіна, Л. Д. Лебедєвої, Є. Г. Макарова. Маючи широкий спектр можливостей, арт-терапія дозволяе вибрати дитині, чим би вона хотіла зайнятися. Як акт творіння арт-терапії підрозділяється на наступні напрямки: бразотворче мистецтво (робота 3 кольором, малюнком, пластиліном, ліплення з глини, аплікація, малювання піском); музична і танцювальна терапія; бібліотерапія (читання прози, віршів, казкотерапія) і імаготерапія (театр, створення образів, ляльок). [6]:

Зображувальна терапія дозволяє висловлювати свої почуття, використовуючи папір, пластилін, фарби, кольоровий папір, олівці та інші зображувальні засоби. У процесі переживання страх вростає в дитину, а дитина вростає в страх, і звільнитись його може бути дуже складно. Використовуючи ж ресурси зображення, ліплення, вона проектує свої страхи на папір, пластилін або глину. Малювання і ліплення також можуть допомогти простежити симптоматику дитячих страхів і причину їх виникнення, а самі продукти діяльності, зламані, зім'яті або викинуті, послужать засобами звільнення негативної психічної напруги. Найкраще, коли дитина домальовує, насичуючи малюнок позитивом чи гумором. Адже емоції страху відступають там, де є сміх і гарний настрій, тобто відбувається процес заміщення негативного позитивним. Якщо страхи дитини уявні (наприклад, негативні казкові персонажі), то даний метод буде дієвий. Таким же чином можна працювати 3 негативними емоціями: образою, почуттям провини і ненавистю [4]. Для дитини дошкільного віку одним із способів пізнання себе, своїх можливостей, а також навколишнього світу зі всілякими моделями поведінки являється малювання. Воно також дозволяє висловити почуття i емоції, включаючи ті, що дитина не усвідомлює. Незважаючи на це не можна стверджувати, ніби дитина, яка часто малює нічого не боїться або зовсім не має труднощів, скоріше, ймовірність появлення страхів у неї значно менше, що вже має важливе значення для ï психічного розвитку [7]. Зображувальна терапія розвантажує нервову систему, заспокоює дитячу психіку і покращує дрібну моторику. Цей метод роботи - один з кращих, так як дозволяє дізнатися, про що думає дитина, чого боїться, соромиться і що iï турбує безпечно та в грі. У процесі малювання відбувається «пожвавлення» 
почуття страху і усвідомлення умовного характеру його зображення. Довірливі відносини, які складаються на занятті між дорослим і дітьми, підсилюють очікуваний результат.

Не менш сильний вплив на дитину здійснює музика і хореографія. Слухаючи музику, граючи на інструментах, дитина активізується, долає негативні установки i відносини, отримує безліч позитивних емоцій і почуттів, вона переключається і забуває про страх, поступово заміщуючи його. Музика розширює дитячу свідомість, роблячи дитину внутрішньо сильнішою і мудрішою. Емоційна сфера, зазнаючи зміни, зміцнюється [7].

Такі напрямки, як бібліотерапія і імаготерапія, що перетинаються в багатьох аспектах, здатні здійснювати не менш сильний вплив. Використовуючи казку, розповідь або вірші, при переказі драматичного твору, в інсценуванні або без неї, ми даємо дитині можливість перевтілитися, а значить, стати впевненим у собі, безстрашним героєм. Для театрального, костюмованого уявлення також можна використовувати ляльок [5].

Психокорекційні вправи, в яких застосовуються методи арт-терапії, мають свої переваги: діти не стомлюються протягом тривалого часу; зберігається висока працездатність, особиста зацікавленість; методи не вимагають великих фінансових витрат; страх, тривожність, дефіцит комунікативної активності легко усуваються творчим процесом і підсумковим результатом.

Механізми розвитку страхів поєднуються між собою, утворюючи мотиваційну структуру. Від того, наскільки ми знайомі з причинами появи страхів і особливостями їх розвитку, буде залежати успішність їх корекції. Важливо розуміння почуттів дитини і того, чого вона хоче; також позитивний приклад батьків буде служити в якості передумови до успішного усунення страхів. Не можна нехтувати страхами дитини, так само як і перебільшувати їх, не можна використовувати страх для маніпуляцій, лаяти і карати за те, що вона боїться, адже батьки несуть відповідальність за стан і самопочуття своєї дитини. Оскільки вплив батьків на дитячу психіку беззаперечний, то здатність дитини протистояти зовнішнім і внутрішнім загрозам буде залежати і від них.

За допомогою малювання в першу чергу вдається усунути страхи, породжені уявою, тобто страхи того, що ніколи не відбувалося, але може статися в прогнозованій реальності дитини. Потім йдуть страхи, засновані на реальних подіях, які спричинили, за собою травму, що відбулися досить давно, але незважаючи на це залишили незабутній емоційний слід у пам'яті дитини. Недостатній ефект від малювання страхів може спостерігатися, якщо травмуючі події відбулися недавно, це може бути укус собаки, аварія та інше. Також не слід боятися пожвавлення страхів в процесі малювання, так як це одна $з$ умов успішної корекції: лише пропрацювавши страх, можна від нього позбутися. Набагато гірше для дитини, якщо страх залишиться всередині і продовжить мучити психіку. У разі, якщо дитина втратила батьків, ми не можемо з етичних причин просити відобразити цей страх [6].

Участь батьків - важливий аспект терапії, вони, як ніхто інший, повинні допомагати дитині в боротьбі з її страхами, прагнути заохочувати дітей до малювання, хвалити і підтримувати, навіть в найдрібніших спробах. Якщо ж батьки самі мають високий рівень страхів і тривожності, то ефект від малювання знизиться практично вдвічі. Також негативно впливатимуть і відсутність життєрадісності, безкінечні переживання і розмови про самопочуття. Подібна атмосфера в родині неминуче вплине на дитину і на процес терапії, зазвичай діти в таких сім'ях менше малюють, грають, в їх роботах помітно переважають темні кольори. Продуктивність від малювання буде залежати і від того, хто дає дитині завдання намалювати страх: якщо це доброзичливий сторонній дорослий, то результат буде вищим, ніж коли завдання дають батьки. Особливо це простежується, якщо батьки дискредитували себе в поданні дітей і намагаються усунути їх страхи, приховуючи свої власні [7].

Дитині може бути дуже складно намалювати свій страх, вона може ухилятися, говорити, що нічого не боїться, запропонувати іншу тему малюнка або просто відмовитися малювати. Як правило, в цьому випадку страх настільки сильний, що дитині страшно навіть думати про нього, не кажучи вже про те, щоб зобразити на папері. Може виникнути і ряд інших причин, наприклад, дитина соромиться свого страху, якщо почуття сорому викликають батьки або значущий дорослий, або вона не бажає визнавати страх, тим більше афішувати. Подібний опір являє собою дію захисних психічних механізмів. У цих випадках необхідно використовувати метод ігротерапії і поступово підвести дитину до того, щоб вона намалювала свій страх. Даний спосіб буде дієвий як в разі сильного страху, так і в ситуації, коли дитина його соромиться або намагається впоратися з емоціями.

Прийнято вважати, що страхи - це емоційні порушення або неприємні нам переживання. У нормі вони виконують функцію самозбереження, тому необхідно для правильного функціонування психіки і побудови поведінки. Однак велика кількість різних страхів у дитини $є$ показником передневротичного стану. У випадку зі страхами, які порушують розвиток особистості, перешкоджають взаємодії з навколишнім світом, спілкування, тобто є патологічними, необхідна спеціальна корекційна і оздоровча психотерапія. 
Висновки 3 даного дослідження і перспективи подалыших розвідок. Вважається, що страхи це емоційні порушення або неприємні нам переживання. Психолого-педагогічний підхід до дослідження страхів умовно можна назвати соціальним. Тут варто звернути увагу в першу чергу на зміни соціального становища дитини, на особливості їі взаємин із зовнішнім світом. Зміст дитячого страху стає тісно пов'язаним з характером міжособистісних знакових соціальних взаємин і визначає соціальні аспекти існування дитини. Важливий аспект у роботі зі страхами є арт-терапії. Вона дозволяє здійснити необхідний вплив м'яко і гуманно, не тільки позбавляючи дитину від страхів, а й сприяючи гармонійному особистісному і психічному розвитку. Таким чином, арт-терапія як метод корекції страхів у дошкільному віці повинна використовуватися для надання психологічної допомоги дитині.

\section{Список використаних джерел:}

1. Захаров О. І. Денні і нічні страхи у дітей / О. І. Захаров. - СПб. : Союз, 2005. - 448 с.

2. Захаров А. І. Походження дитячих неврозів і психотерапія / А. І. Захаров. - СПб. : ЕКСМО-Прес, 2000. - 448 c.

3. Копитін О. І. Арт-терапевтичні методи, використовувані в роботі з дітьми та підлітками: огляд сучасних публікацій / О. І. Копитін // Журнал практичної психології та психоаналізу. - 2007. № 4. - C. 1-26.

4. Кисільова М. В. Арт-терапія в роботі з дітьми: керівництво для дитячих психологів, педагогів, лікарів і фахівців, що працюють $з$ дітьми / М. В. Кисільова. - Київ : Мова, 2009. - 160 с.

5. Корсакова Н. А. Музична терапія в музичному благополуччя дошкільника / Н. А. Корсакова // Вихователь ДНЗ. - 2016. - № 2. - С. 29.

6. Поштарьова Т. Р. Використання народних казок у освітньому процесі / Т. Р. Поштарьова // Дошкільне виховання. - 2009. - № 5. - С. 24-28.

7. Орлов А. Б. Психологічні механізми виникнення і корекції нав'язаних дитячих страхів / А. Б. Орлов, Л. В. Орлова, Н. А. Орлова // Питання психології. - 2011. - № 3. - С. 7.

\section{References:}

1. Zaharov A. I. Dnevnye i nochnye strahi u detej / A. I. Zaharov. - SPb. : Sojuz, 2005. - 448 p.

2. Zaharov A. I. Proishozhdenie detskih nevrozovipsihoterapija / A. I. Zaharov. - SPb. : JeKSMOPress, 2000. -448 p.

3. Kopytin A. I. Art-terapevticheskie metody, ispol'zuemye v rabote s det'mi i podrostkami: obzor sovremennyh publikacij / A. I. Kopytin, E. E. Svistovskaja // Prakticheskoj Psihologii i Psihoanaliza. 2007. - № 4. - P. 1-26.

4. Kiseleva M. V. Art-terapija v rabote s det'mi: rukovodstvo dlja detskih psihologov, pedagogov, vrachej i specialistov, rabotajushhih s det'mi / M. V. Kiseleva. - Kyyiv : Rech', 2009. - 160 p.

5. Korsakova N. A. Muzykal'naja terapija v muzykal'nom blagopoluchii doshkol'nika / N. A. Korsakova // Vospitatel' DOU. - 2016. - № 2. - P. 29.

6. Poshtareva T. Ispol'zovanie narodnyh skazok v obrazovatel'nom processe / T. Poshtareva // Doshkol'noe vospitanie. - 2009. - № 5. - P. 24-28.

7. Orlov A. B. Psihologicheskie mehanizmy vozniknovenija i korrekcii vnushennyh detskih strahov / A. B. Orlov, L. V. Orlova, N. A. Orlova // Voprosypsihologii. - 2011. - № 3. - P. 7.

\section{Stepaniuk CORRECTION OF CHILDREN'S FEARS IN PRESCHOOL BY METHODS OF ART-THERAPY}

It is believed that fears are emotional disturbances or unpleasant experiences. Psychologypedagogical approach to the study of fears can be conventionally called social. In the article it is paying attention first of all to changes in the social situation of the child, on the peculiarities of relationship with the outside world. The content of childhood's fear is closely linked to the nature of interpersonal sign social relationships and defines the social aspects of the existence of the child.

The author submitted the analysis of literary sources on this problem, has shown the existence of fear in children associated with the symbolic structures of consciousness, from mythological thinking - the fear of different mythological characters, which may be a superstructure over all other childish fears and related to the cultural and historical development of society.

It is important to remember that art therapy is intended for self-expression of internal experiences, self-knowledge through creativity and enhancement of the adaptive functions of the individual, so the main task will not be to teach a child to draw, but rather use the picture as a projection. In connection with this, 
there may be a number of problems, one of which is the child's fear of doing something wrong, since it can survive in a timely manner. An important aspect in working with fears is art therapy - it is the participation of parents, they, like no other, should help the child in their struggle with her fears, strive to encourage children to draw, praise and support, even in the smallest attempts.

Art therapy also allows you to effect the necessary influence gently and humanely, not only depriving the child of fears, but also contributing to the harmonious personality and mental development. Thus, art therapy as a method of correction of fears in the preschool age should be used to provide psychological assistance to the child.

Key words: fear, preschool age, art therapy, personality development, psychocorrection, play activity, image therapy. 